\title{
Publiceringsgenvej i OJS
}

Send din færdigformaterede fil uden om det redaktionelle workflow og direkte til elektronisk publicering

Denne publiceringsform er kun tilgængelig, såfremt du både indtager rollen som forfatter og redakt $\varnothing r$ 


\section{Publiceringsgenvej i OJS}

Gå ind på siden 'BRUGERSTARTSIDE' (1) og vælg indgangen 'Forfatter' (2)

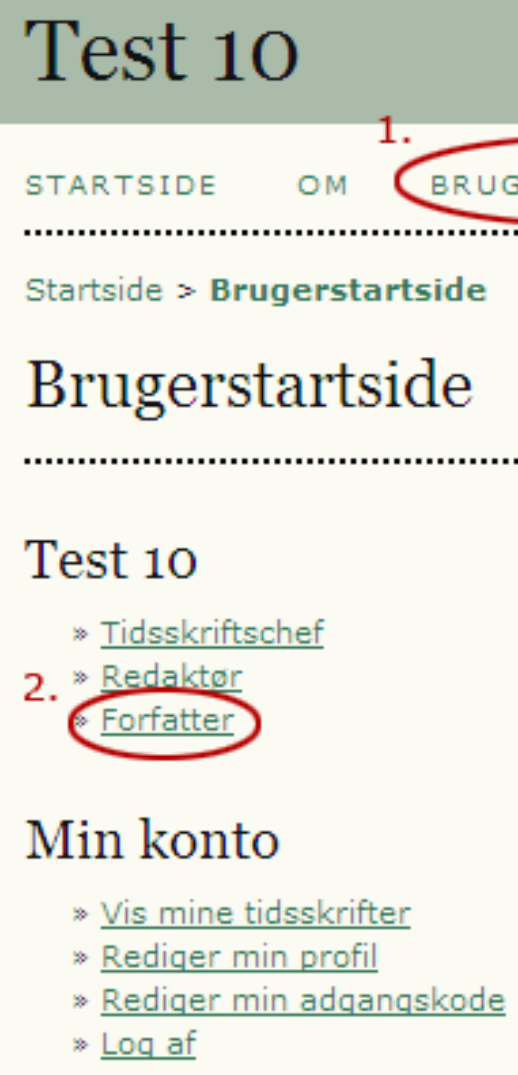




\section{Publiceringsgenvej i OJS}

Påbegynd den samme proces, som du tager i brug ved almindelig publicering ved at aktivere linket 'KLIK HER'.

\section{Test 10}

STARTSide OM BRugerstartside Søg AKTUEL ARKiver Meddelelser

Startside $>$ Bruger $>$ Forfatter $>$ Aktive manuskripter

Aktive manuskripter

AKTIV ARKIV

$M M-D D$

ID FREMSEND SEK FORFATTERE

TITEL

STATUS

Ingen manuskripter

Start et nyt manuskript

KLIK HER for at gå til trin 1 af de fem trin, som manuskriptprocessen består af. 


\section{Publiceringsgenvej i OJS}

\section{Sektion vælges, manuskripttjeklisten markeres* og der klikkes på 'Gem og forsæt'.}

* såfremt den eller flere er tilvalgt i tidsskriftsopsætningen

\section{Test 10}

startside om Brugerstartside søg aktuel arkiver meddelelser

Startside > Bruger > Forfatter > Manuskripter > Nyt manuskript

Trin 1. Start af manuskriptet

1. START 2. ANGIV METADATA 3, OVERFØR MANUSKRIPT 4. OVERFØR SUPPLERENDE FILER 5, BEKR AETTELSE

Er du stødt på vanskeligheder? Kontakt Niels for at få hjælp.

Tidsskriftssektion

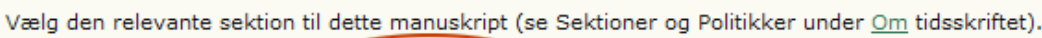

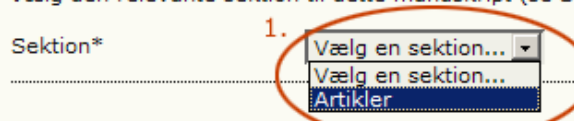

Manuskripttjekliste

Angiv, at dette manuskript er klar til at blive vurderet af dette tidsskrift ved at afkrydse følgende (kommentarer til redaktøren kan tilføjes nedenfor)

(1) Manuskriptet er ikke tidligere blevet publiceret, og det er heller ikke sendt til et andet tidsskrift med henblik på at komme betragtning til at blive publiceret (eller der er angivet en forklaring under Kommentarer til redaktøren).

Tidsskriftets erklæring om beskyttelse af personlige oplysninger

De navne og adresser, der angives på dette tidsskrifts websted, vil udelukkende blive anvendt til tidsskriftets angivne formål og vil ikke blive gjort tilgængelige til andre formål eller for andre parter.

Kommentarer til redaktøren

Angiv tekst (valgfri) 


\section{Publiceringsgenvej i OJS}

Da du i første omgang er registreret som både forfatter og redakt $\varnothing r$ indskrives dine persondata i forfatterfeltet.

Dette skal nu tilrettes, såfremt du ikke er forfatter til artiklen.

Titel og resumé indskrives ligesom øvrige relevante felter udfyldes.

Hvis dit tidsskrift anvender flere formularsprog vælges disse i $\varnothing$ verste dropdownmenu ud for feltet 'F ormularsporg'. Hver sprogflade kræver nyindskrivning i feltet titel og resumé.

\section{Test 10}

STARTSide OM BRugerstartside Søg aKTuel ARKiver MedDelelser

Startside $>$ Bruger $>$ Forfatter $>$ Manuskripter $>$ Nyt manuskript

Trin 2. Angivelse af manuskriptets metadata

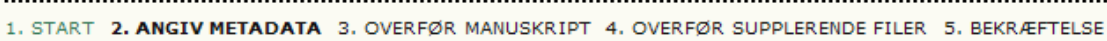

Forfattere

Fornavn*

Mellemnavn

Efternavn*

Tilhørsforhold

Land

E-mail*

URL-adresse

Biografierklæring

(f.eks. afdeling og rang)

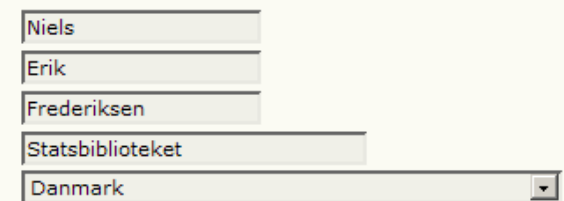

\section{Danmark}

nef@statsbiblioteket.dk

Studie- og forskningsservice,

Fagreferent

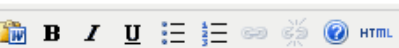

Tilføj forfatter

\section{Titel og resumé}

Titel*

Resumé*

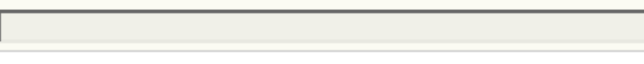

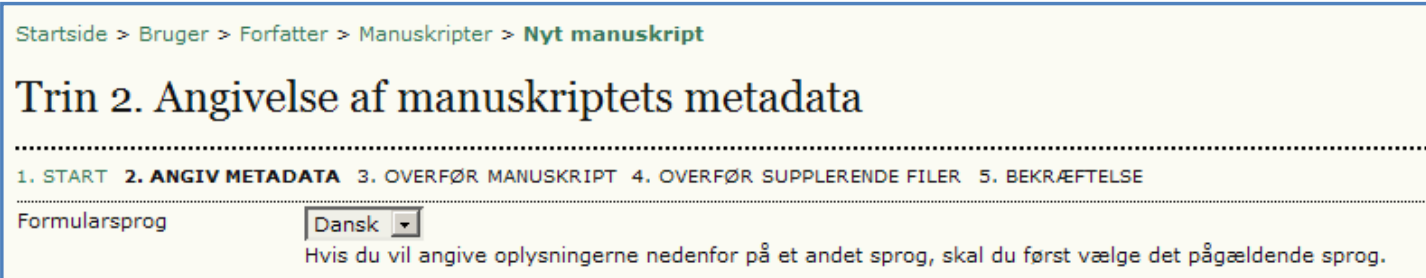




\section{Publiceringsgenvej i OJS}

På den efterfølgende side indsættes den færdigformaterede fil (f.eks. en pdf) via 'Gennemse...' (1). Klik dernæst på 'Overfør' (2) og 'Gem og fortsæt' (3).

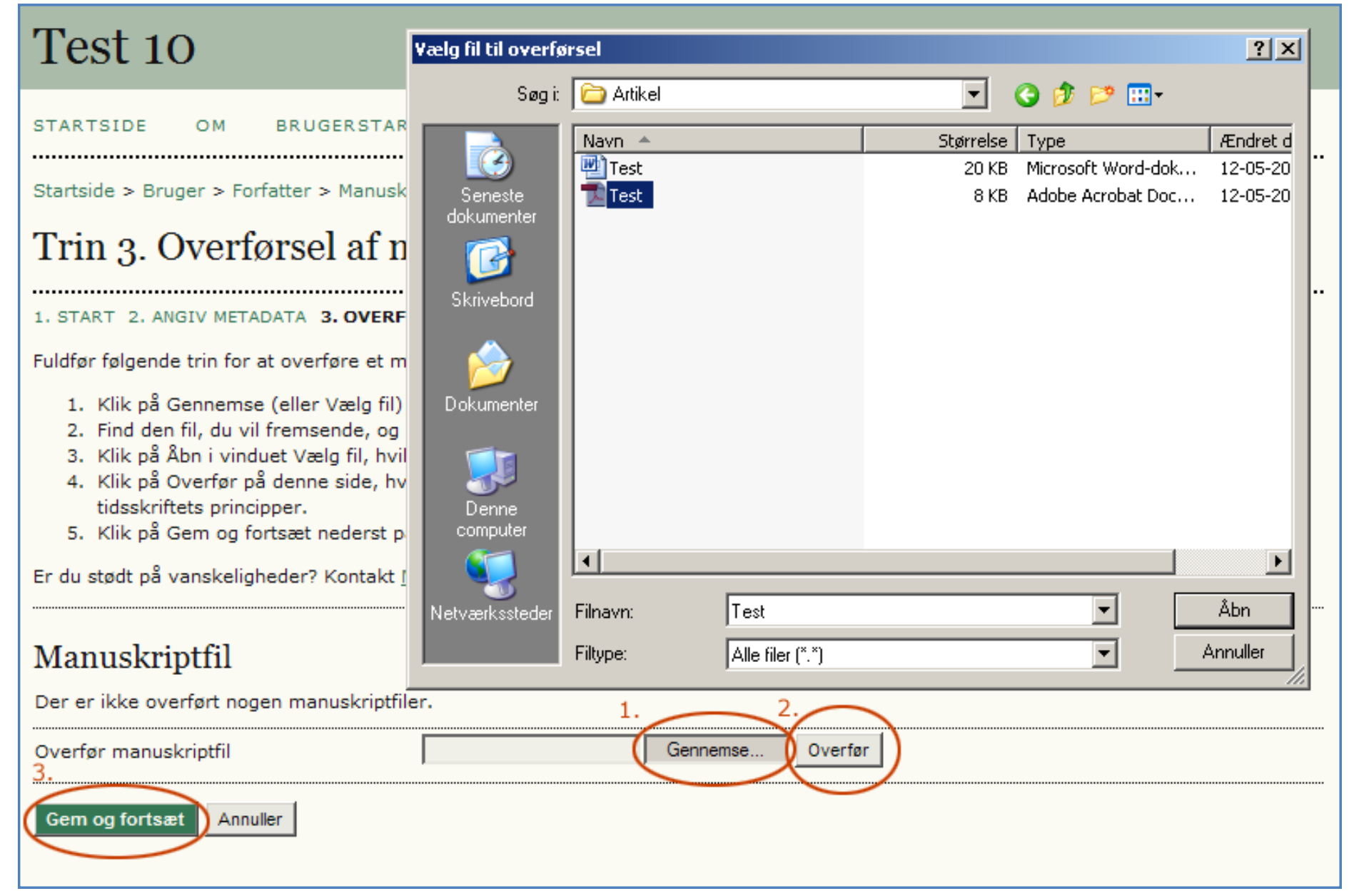




\section{Publiceringsgenvej i OJS}

Herefter tildeles den overførte fil automatisk et specifikt filnavn. Tryk derefter igen på knappen 'Gem og fortsæt'.

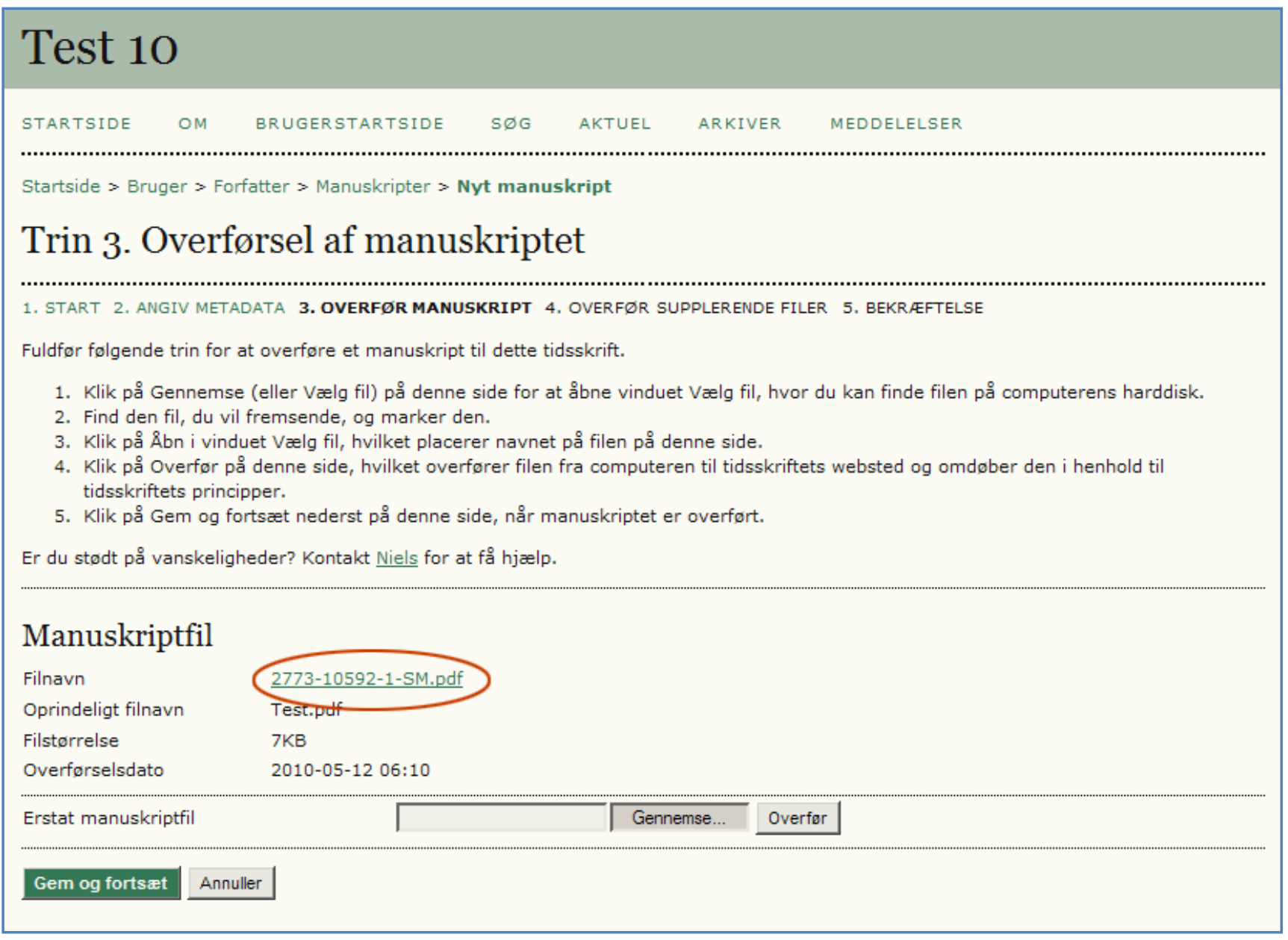




\section{Publiceringsgenvej i OJS}

Med mindre ekstrafiler skal overføres går du videre med et klik på knappen 'Gem og fortsæt'.

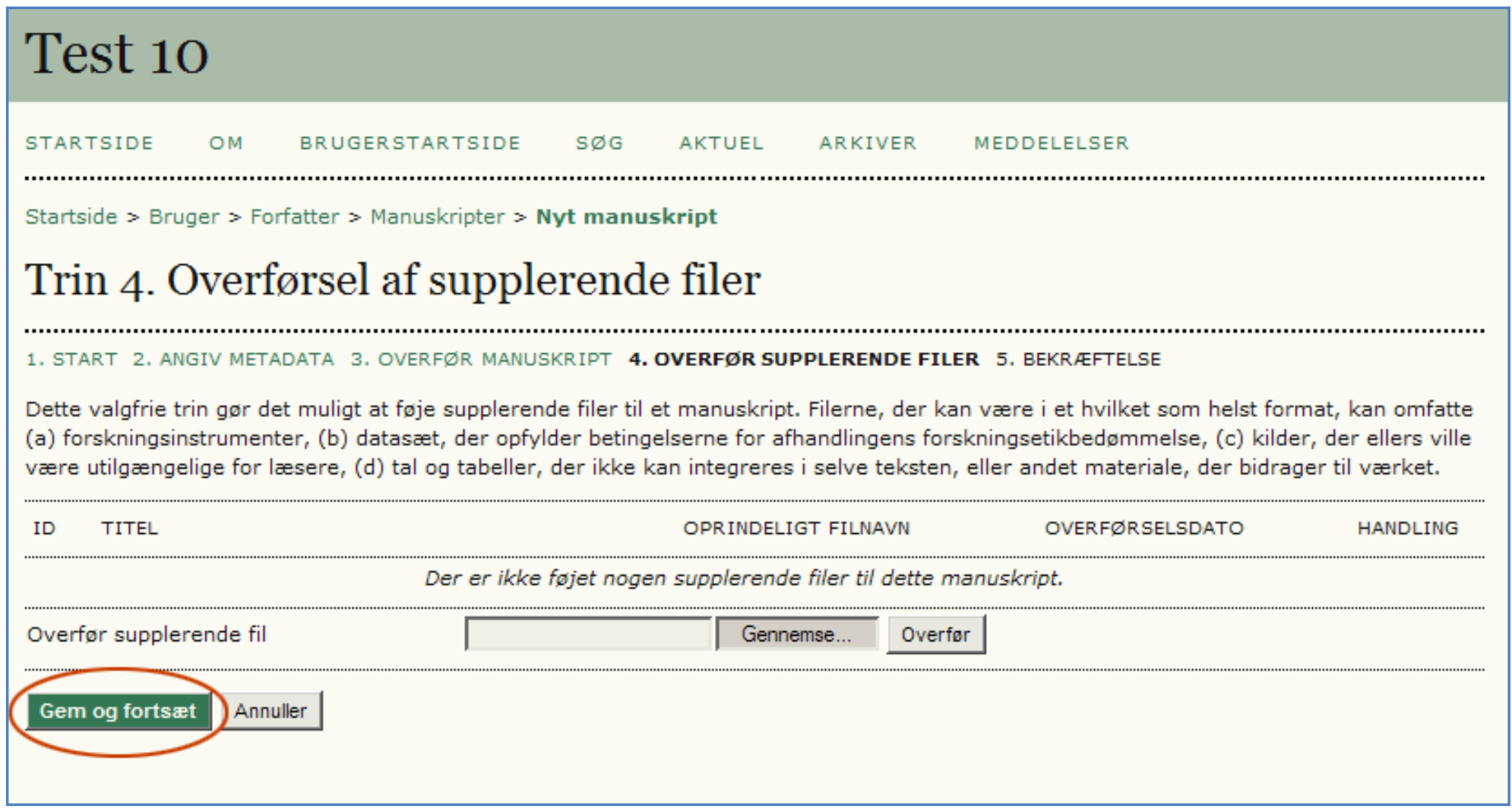




\section{Publiceringsgenvej i OJS}

Her klikkes der så blot på knappen 'Afslut manuskript'.

Normalt ville denne side være slutside i forbindelse med forfatterens overførsel af manuskript, men da du også er redaktør, fremkommer der endnu en mulighed (se efterfølgende side).

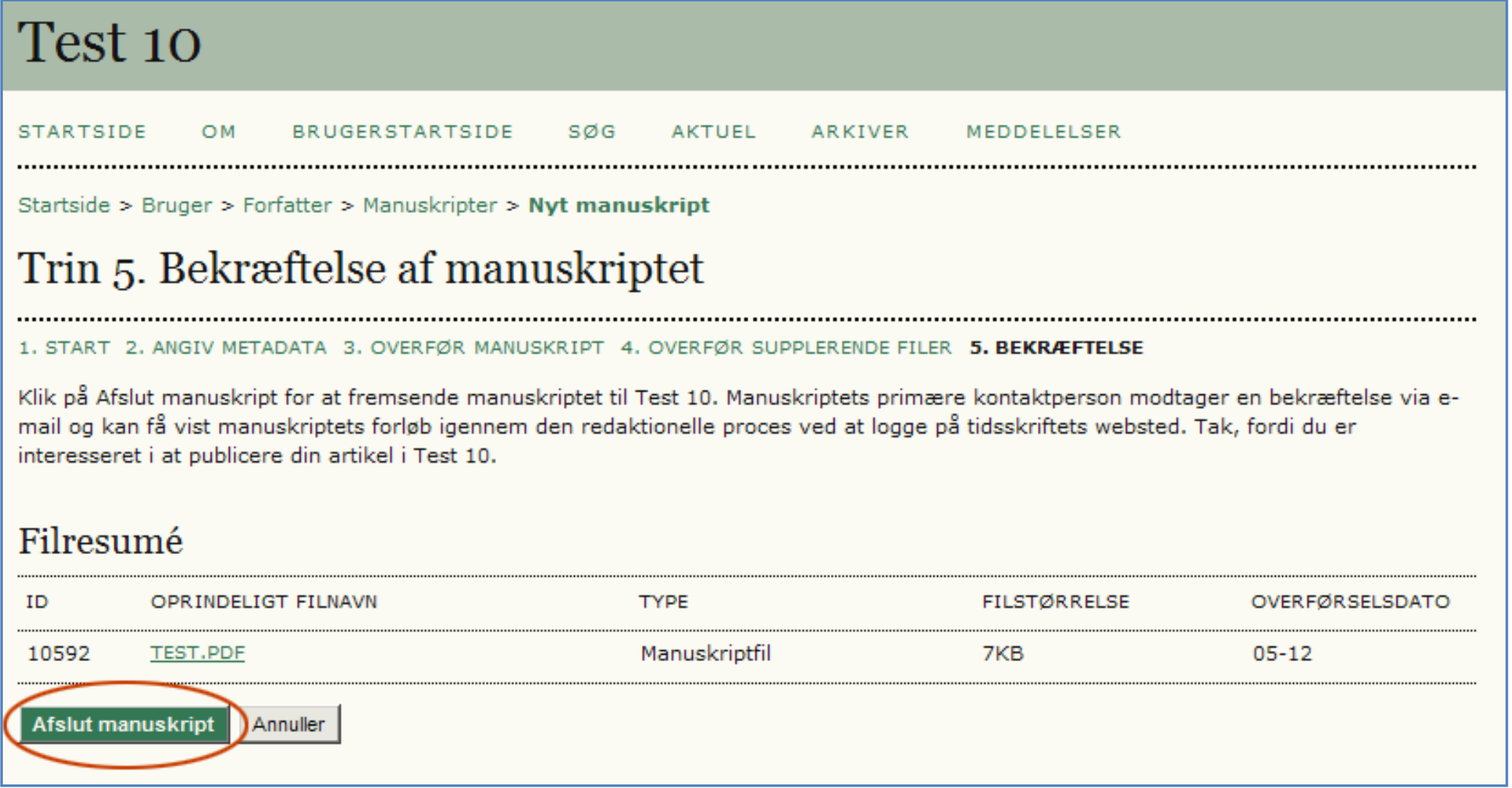




\section{Publiceringsgenvej i OJS}

\section{Test 10}

STARTSIDE OM BRUgERTARTSIDE SøG AKTUEL ARKIVER MEDDELESER

Startside $>$ Bruger $>$ Forfatter $>$ Manuskripter $>$ Aktive manuskripter

Aktive manuskripter

Manuskriptet er fuldført. Tak, fordi du er interesseret i at publicere din artikel i Test 10.

Hvis manuskriptet er i et format, der er klar til at blive publiseret uden yderligere bedømmelse, redigering eller layout, kan du placere det direkte i den sidste fase af redigeringskøen ved of KLIKKE HER. Bemæerk! Det er kun tidsskriftsredaktører, der har denne mulighed med hensyn til deres manuskripter).

» Aktive manuskripter

For at blive sendt uden om hele redigeringsprocessen klikker du på linket 'KLIKKE HER'. Herefter kan du gå direkte til publiceringen (se næste side). 


\section{Publiceringsgenvej i OJS}

Du er nu fremme ved den redaktionelle afslutning. Under afsnittet 'Planlægning' vælger du, i dropdownmenuen, blot den udgave artiklen skal publiceres i (1). Efterfølgende klikkes på knappen 'Post' (2).

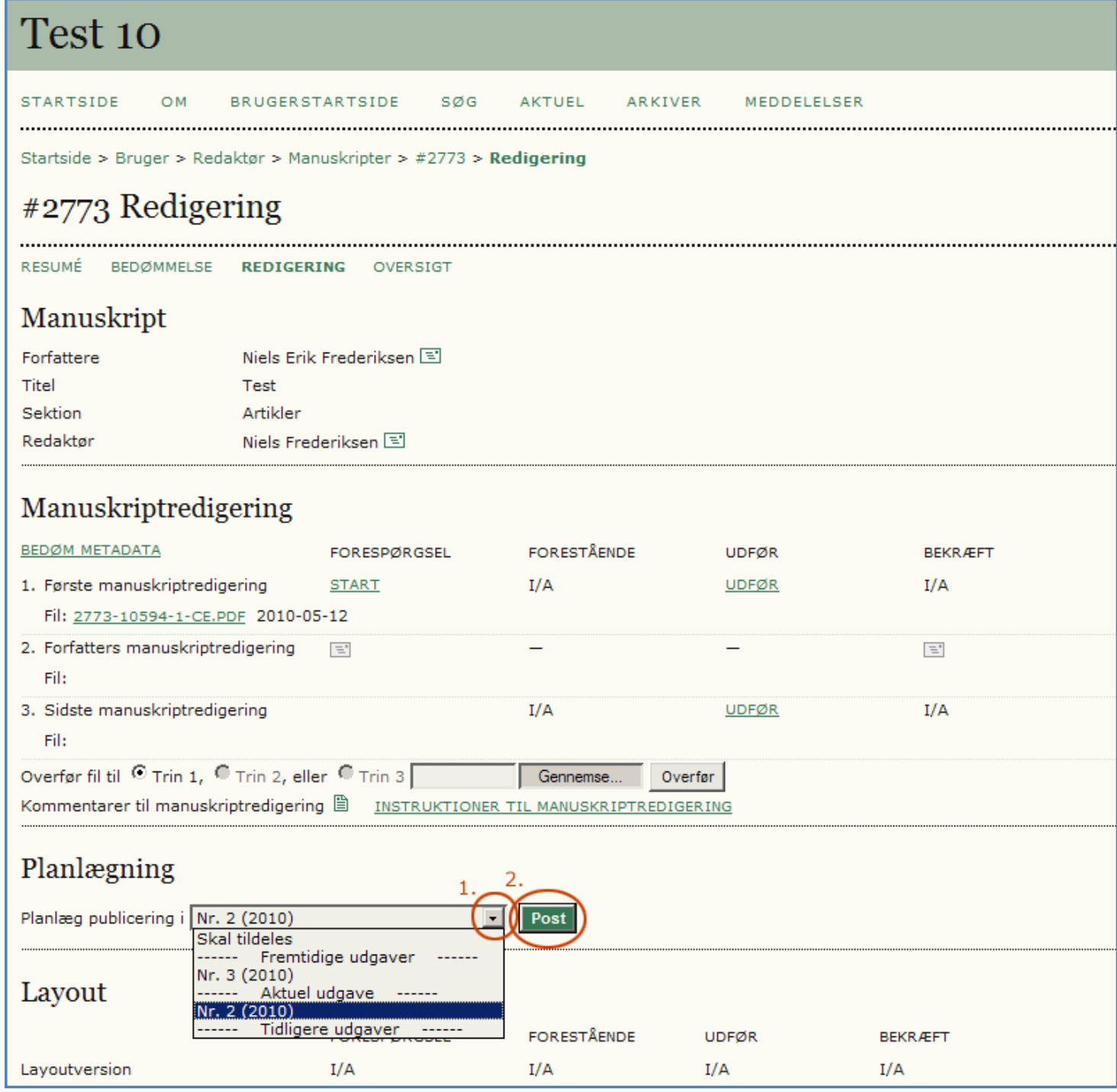




\section{Publiceringsgenvej i OJS}

Såfremt det valgte nummer, her Nr. 2 (2010), allerede er publiceret, er artiklen nu online tilgængelig og kan nås via topmenuen.

Efter at have klikket på knappen 'Post' fremkommer linket 'INDHOLDSFORTEGNELSE'. Hvis nummeret endnu ikke er publiceret og dette $\varnothing$ nskes, aktiveres dette (se næste side).

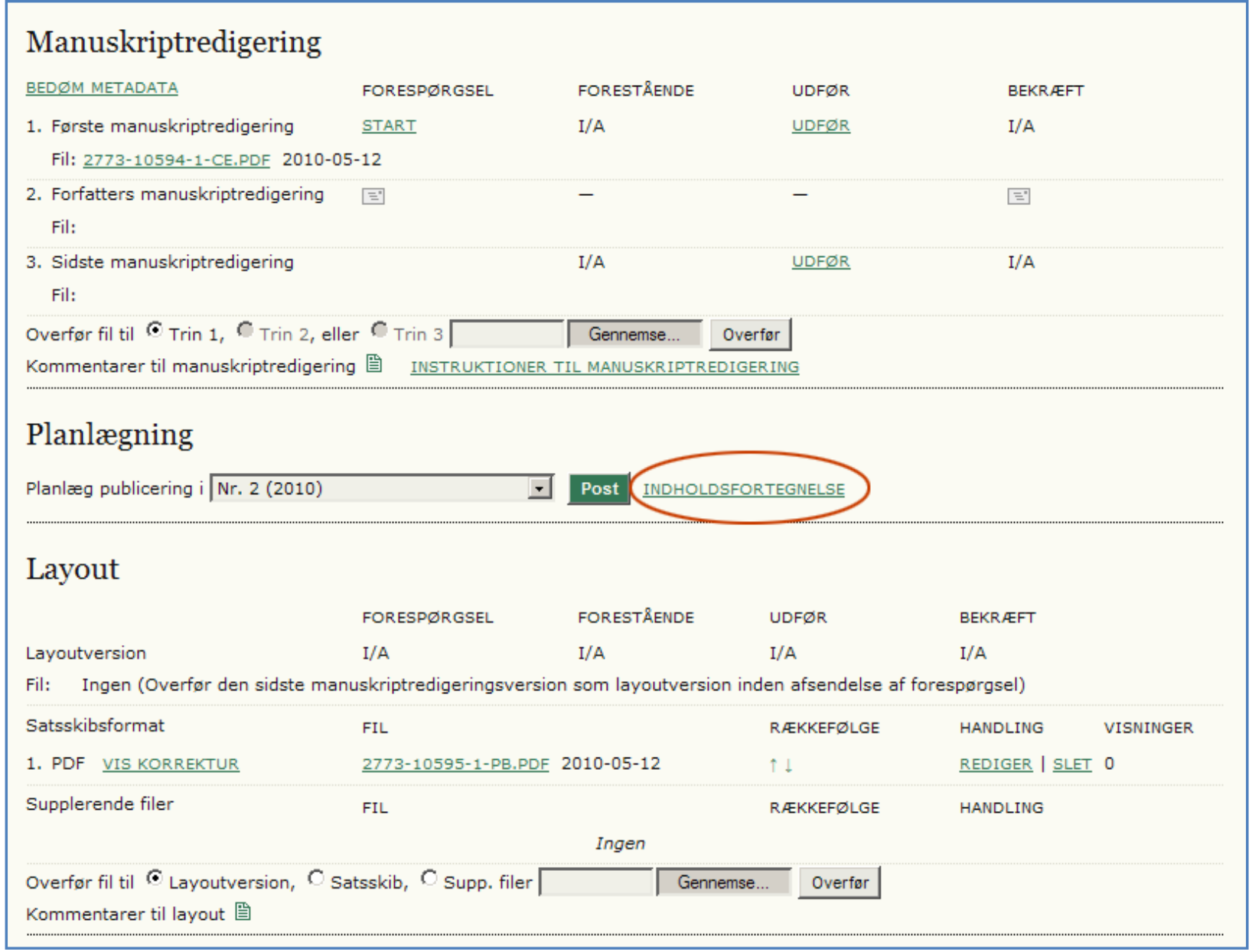




\section{Publiceringsgenvej i OJS}

Når man ønsker at udgive en endnu ikke publiceret udgave klikkes på knappen 'Publicér udgave'. Herefter skifter den fra 'Fremtidig udgave' til 'Aktuel'.

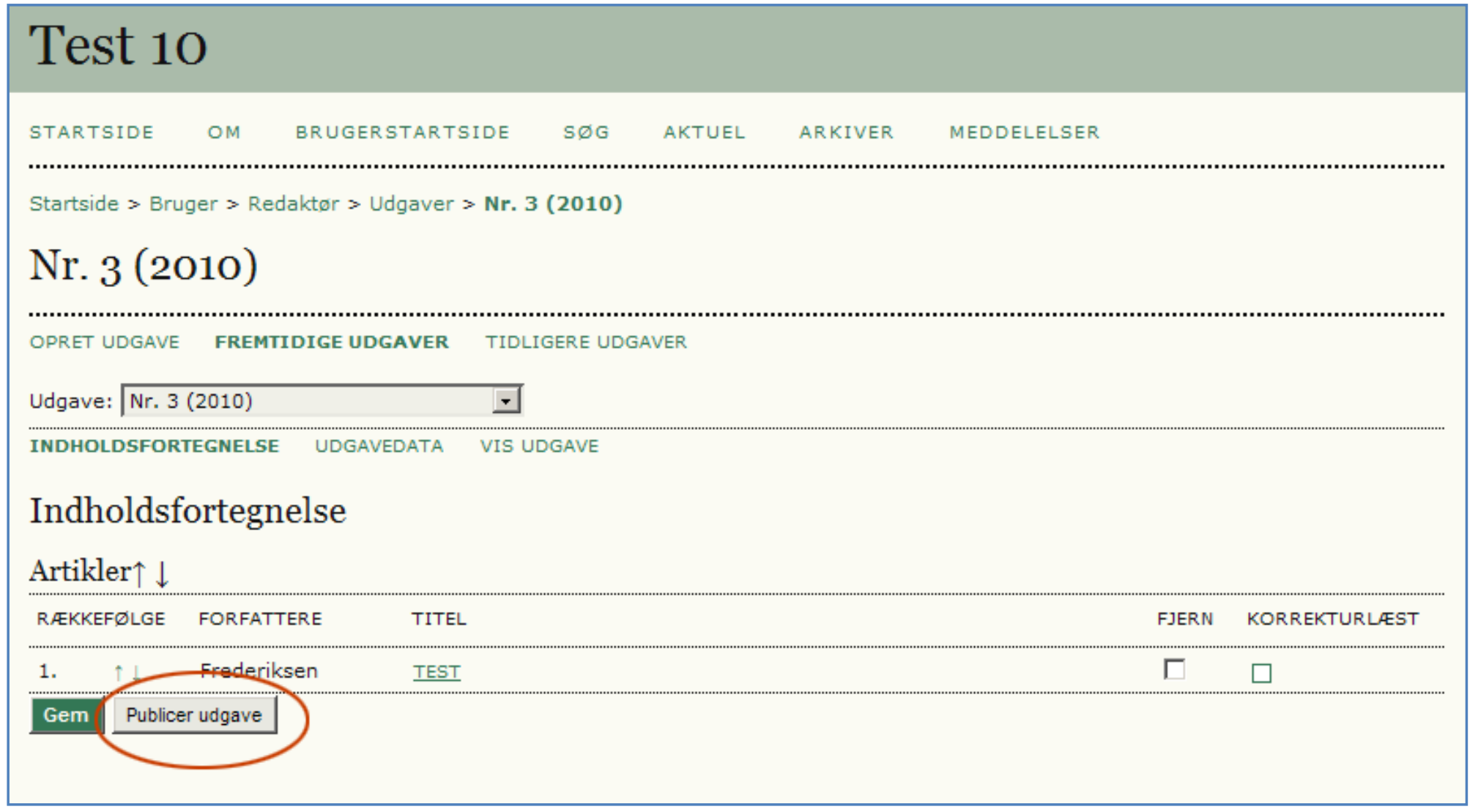




\section{Publiceringsgenvej i OJS}

Det kan forekomme, at programmet ikke får registreret hvilket filformat, der er uploadet. Hvis det er tilfældet vil der i stedet for PDF (1) stå IKKE-NAVNGIVET. Det ændres blot ved at klikke på linket 'REDIGER' (2).

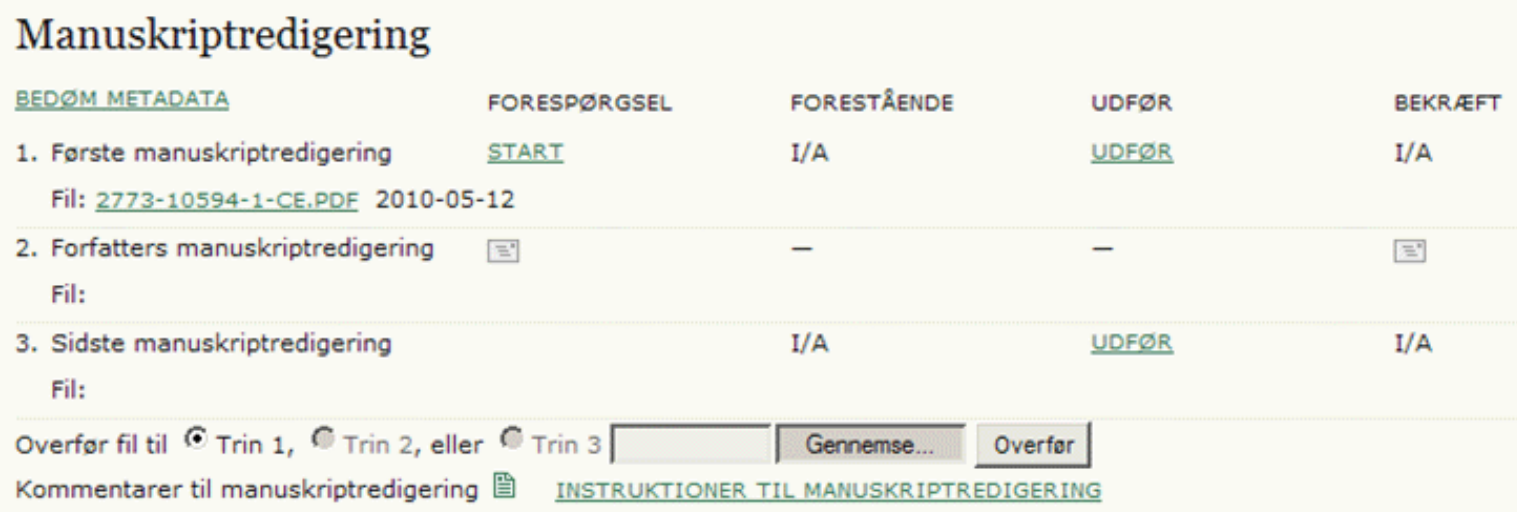

3. Sidste manuskriptredigering Fil:

Planlægning

Planlæg publicering i $\mathrm{Nr}$. 2(2010)

Post INDHOLDSFORTEGMELSE

Layout

$\begin{array}{lllll} & \text { FORESPøRGSEL } & \text { FORESTAENDE } & \text { UDFøR } & \text { BEKREFT } \\ \text { Layoutversion } & \text { I/A } & \text { I/A } & \text { I/A } & \text { I/A }\end{array}$

Fil: Ingen (Overfor den sidste manuskriptredigeringsversion som layoutversion inden afsendelse af foresporgsel)

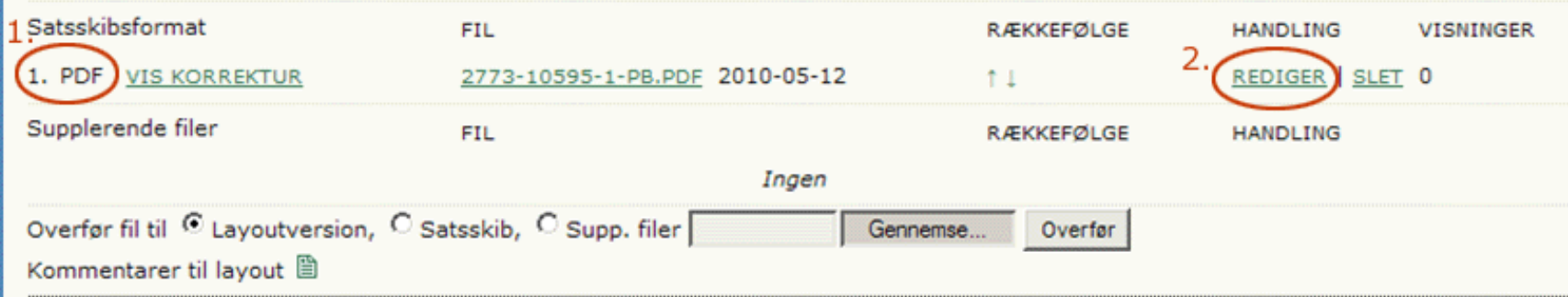




\section{Oprettelse af ny udgave}




\section{Oprettelse af ny udgave}

Når du skal have oprettet et nyt nummer, skal du gå ind som redaktør og på startsiden vælge 'Opret udgave'.

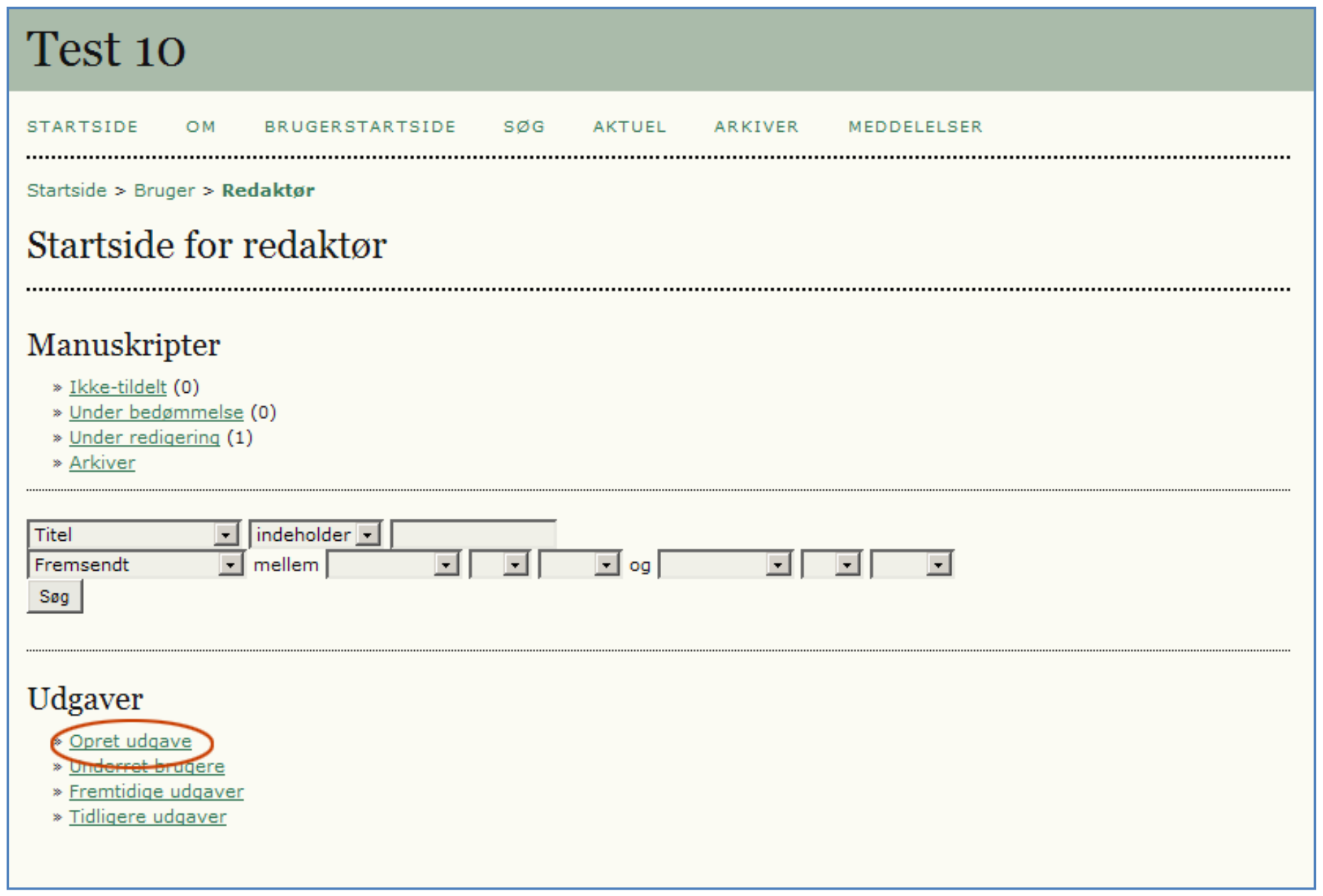




\section{Oprettelse af ny udgave}

Under afsnittet 'Identifikation' indsættes de relevante oplysninger.

Under afsnittet 'Forside' er der bl.a. mulighed for at indsætte forsidebillede - et slags omslagsbillede.

Når informationerne er indlagt klikkes på knappen 'Gem'.

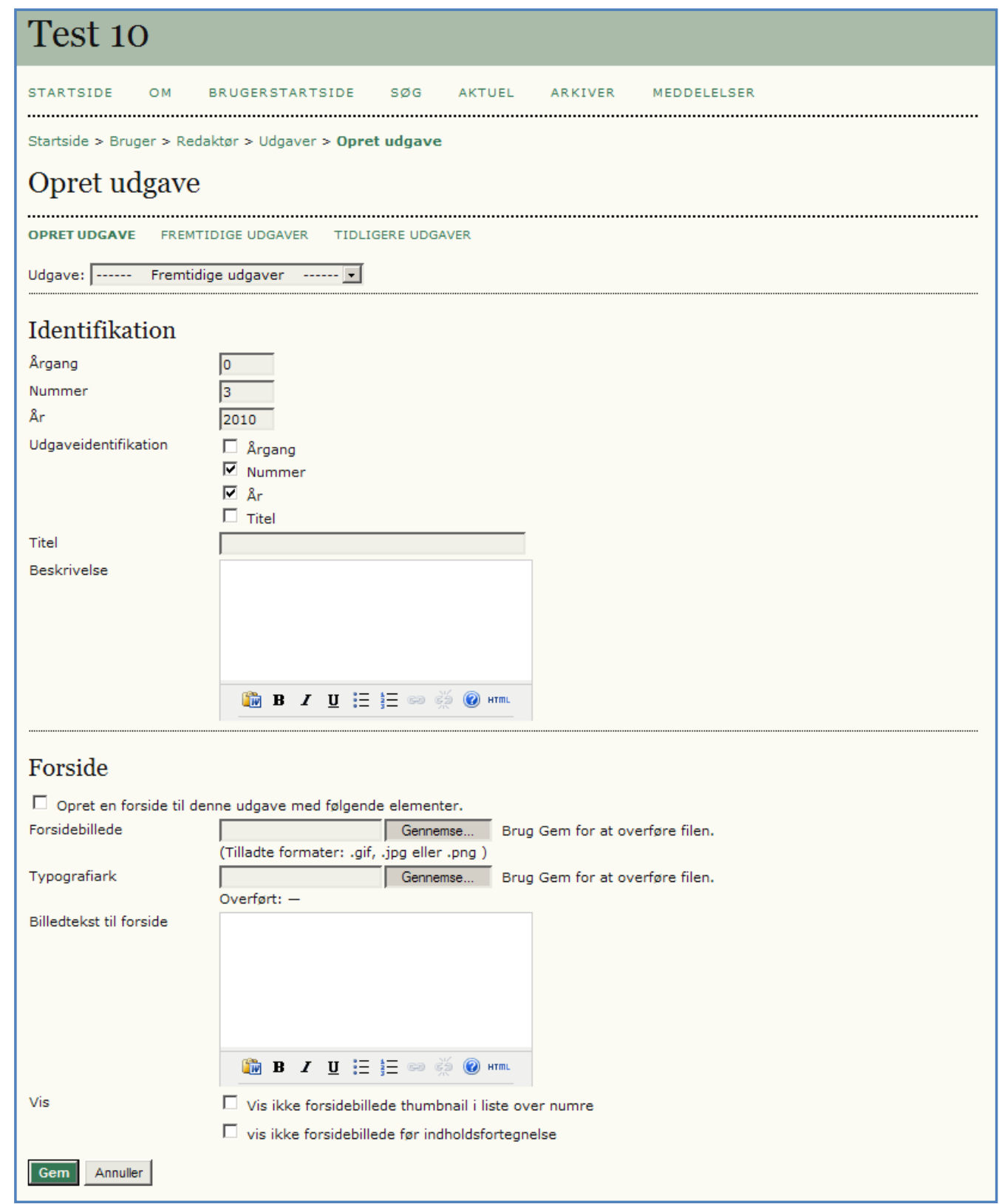




\section{Oprettelse af ny udgave}

\section{På den fremkomne side vælges linket 'FREMTIDIGE UDGAVER'.}

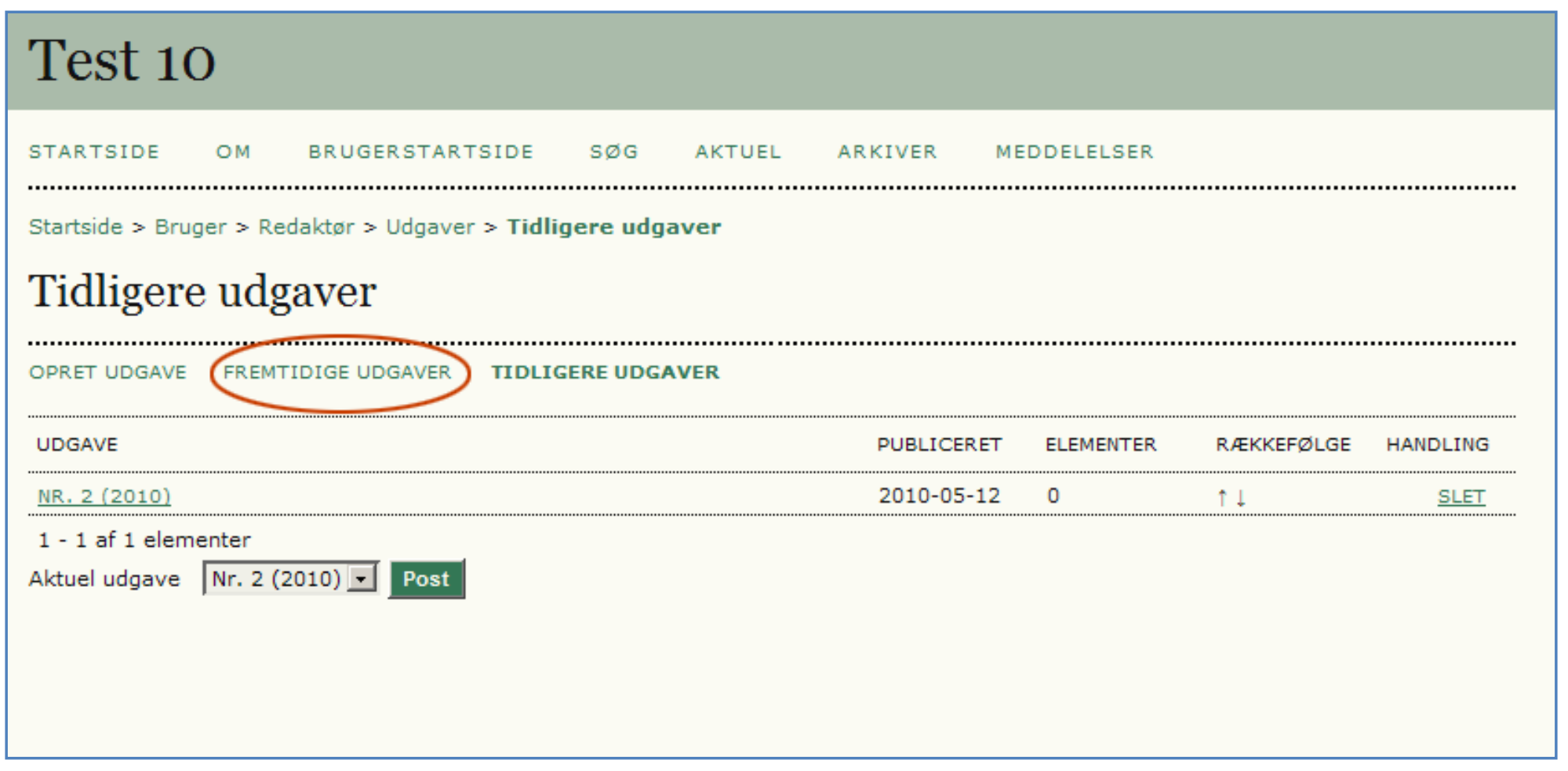




\section{Oprettelse af ny udgave}

Her er der nu adgang til den nyoprettede udgave. Klik på det markerede link.

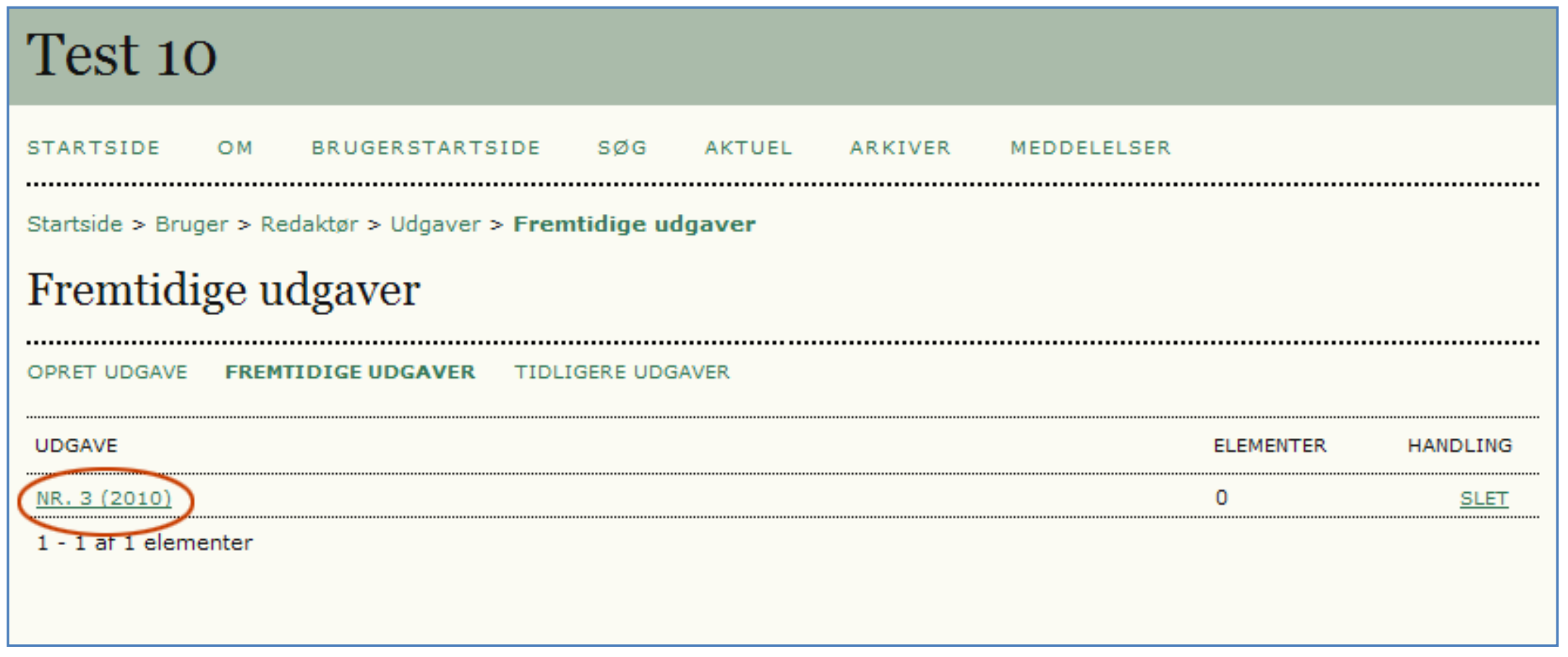




\section{Oprettelse af ny udgave}

Herefter kan nummeret publiceres via knappen 'Publicér udgave'.

De fleste vælger nok først denne mulighed, når de planlagte artikler er lagt ind (se ovenfor).

Og dog - med online publicering vil flere og flere nok vælge at publicere fortl $\varnothing$ bende inden alle artikler er forfattet.

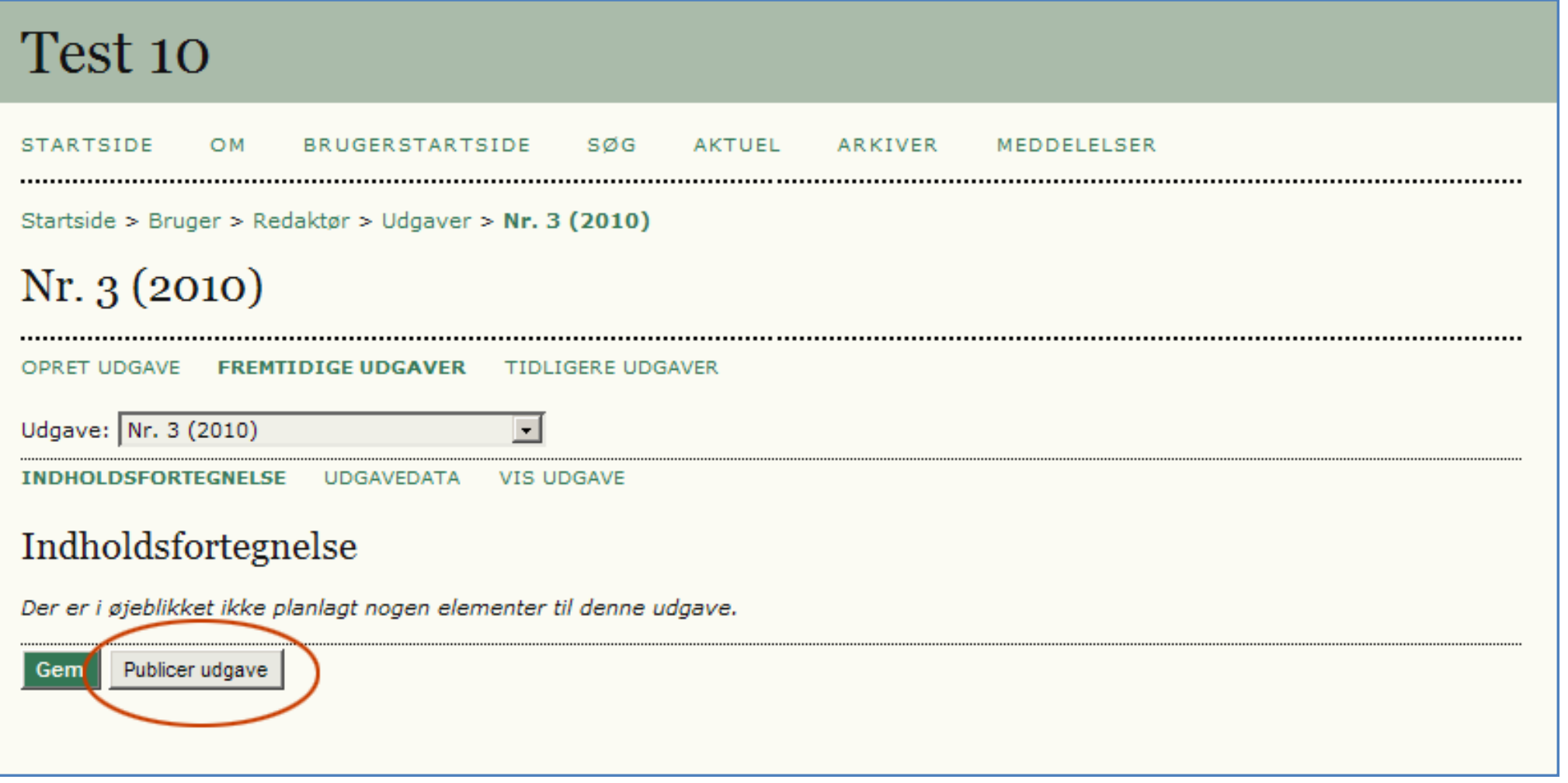




\section{SLUT}

Niels Erik Frederiksen - Statsbiblioteket - nef@statsbiblioteket.dk 